\title{
Retinol, cholecalciferol and alpha-tocopherol contents of Bulgarian Black Sea fish species
}

\author{
Mona STANCHEVA, Diana A. DOBREVA* and Bistra GALUNSKA
}

Faculty of Pharmacy, Medical University of Varna, 55 Marin Drinov Str., 9002 Varna, Bulgaria

\begin{abstract}
The aim of the present study is to determine and to compare the content of retinol, cholecalciferol and alpha-tocopherol in edible tissue of two Black sea fishes - Garfish (Belone belone) and Turbot (Psetta maxima). All-trans-retinol (vitamin A), cholecalciferol (vitamin $\mathrm{D}_{3}$ ) and alpha-tocopherol (vitamin E) were analyzed simultaneously using HPLC/UV/FL system (Thermo Scientific Spectra SYSTEM) equipped with RP analytical column. The mobile phase was composed of 97:3 = MeOH: $\mathrm{H}_{2} \mathrm{O}$. Retinol and cholecalciferol were monitored by UV detection at $\lambda_{\max }=325 \mathrm{~nm}$ and $\lambda_{\max }=265 \mathrm{~nm}$, respectively. Alpha-tocopherol was detected by fluorescence at $\lambda_{\mathrm{ex}}=288 \mathrm{~nm}$ and $\lambda_{\mathrm{em}}=332 \mathrm{~nm}$. The sample preparation procedure includes alkaline saponification, followed by liquid-liquid extraction. Quantities of all-trans-retinol and cholecalciferol were higher in garfish tissues while alpha-tocopherol content in turbot showed seven times higher values.
\end{abstract}

Keywords: retinol, cholecalciferol, alpha-tocopherol, turbot, garfish, HPLC

\section{Introduction}

Fish is considered as a valuable source of essential nutrients - macronutrients as proteins and fats, and micronutrients as vitamins and minerals, and is an important component of balanced human diet. Fat soluble vitamins are essential components of fish lipids and are exclusively provided by the diet.

Fat soluble vitamins control a variety of biologically important processes in human body. All-trans retinol (vitamin A), takes place in photoreception and regulates gene expression and cell division, bone growth, teeth development, reproduction etc. Cholecalciferol (Vitamin $\mathrm{D}_{3}$ ) promotes and enhances the absorption and the metabolism of calcium and phosphorus. Alphatocopherol is vitamin $\mathrm{E}$ isomer with the highest biological activity. Its main role is as antioxidant, protecting membrane structures, essential fatty acids, and vitamins $\mathrm{A}$ and $\mathrm{C}$ against oxidation [1].

Fish production in Bulgaria comes mainly from commercial fishing. The catches in the Black Sea account about $77.3 \%$ of total fish production for the country. Aquaculture production (including fresh water fish farming and marine farming of fish and mussels) accounts approximately $13.8 \%$ of the total fish production [2].

As a delicious Black sea fishes Turbot (Psetta maxima) and Garfish (Belone belone) are consumed in significant amounts in Bulgaria.

Garfish is characterized with long thin body and long needle like mouths. Adult species can reach up to $1 \mathrm{~m}$ in length and are mostly silver in color with a blue to green back side and green skeleton. They are typical pelagic fishes. The garfishes are omnivorous - they prefer to feed on zooplankton and small fishes [3].

Some of the Black Sea fish species have migratory character (like garfish), others are nonmigratory and they are subject of perennial fishing. One of this species is the Black sea turbot. Psetta maxima is one of the flatfish species. They are characterized with white meat and usually low lipid levels. The turbots live near the marine floor - in softer bottoms of mud and sandy mud. They fed 
with crustaceans, squid, and with a variety of small fish species. In some countries turbots are raised with commercial goal [3, 4].

The aim of the present study was to evaluate and to compare the content of fat soluble vitamins (A, $\mathrm{D}_{3}, \mathrm{E}$ ) in raw edible tissue of two delicious Black sea fish species - garfish and turbot.

\section{Experimental}

\subsection{Fish species}

Samples of turbot and garfish were purchased from Varna fish market during autumn 2009. All fishes were immediately frozen at $-20^{\circ} \mathrm{C}$ and stored in a refrigenator at the same conditions. Several specimens of each fish species were used as a raw material for vitamin analysis. The biologic characteristics of the fishes were determined and noted in Table 1.

Table 1 Biometric and biologic characteristics of studied fishes

\begin{tabular}{|l|c|c|}
\hline $\begin{array}{l}\text { Biometric/biologic } \\
\text { parameter }\end{array}$ & $\begin{array}{c}\text { Turbot } \\
(\mathrm{n}=3)\end{array}$ & $\begin{array}{c}\text { Garfish } \\
(\mathrm{n}=9)\end{array}$ \\
\hline $\begin{array}{l}\text { Total weight average } \\
(\mathrm{g} \pm \mathrm{SD})\end{array}$ & $1480.0 \pm 175.5$ & $62.0 \pm 14.3$ \\
\hline $\begin{array}{l}\text { Mean total length } \\
(\mathrm{cm} \pm \mathrm{SD})\end{array}$ & $43.8 \pm 4.3$ & $37.0 \pm 3.4$ \\
\hline Habitat & Demersal & Pelagic \\
\hline Food habits & Carnivorous & $\begin{array}{c}\text { Omnivoro } \\
\text { us }\end{array}$ \\
\hline
\end{tabular}

\subsection{Standards and reagents}

All-trans-retinol was purchased from Fluka, cholecalciferol, alpha-tocopherol, and other HPLCgrade reagents - from Sigma-Aldrich ${ }^{\mathrm{TM}}$.

\subsection{Sample preparation}

Prior to analysis the fishes were gently defrosted; the head, tail, fins, and viscera were removed. The fishes were filleted and homogenized together with the skin and used as raw material for preparation of random sample of fish tissue. The sample preparation was performed using the modified from us method of Sanchez-Machado [5].

An aliquot of the homogenized tissue $(1.000 \pm 0.005 \mathrm{~g})$ was weighed into a glass tube with a screw cap and $1 \%$ of methanolic L-ascorbic acid and
1M methanolic potassium hydroxide were added. Six parallel samples of edible fish tissue were prepared and saponified at $80^{\circ} \mathrm{C}$ for 20 minutes. After cooling the lipids were extracted with nhexane. The extracts, containing fat soluble vitamins were evaporated under nitrogen. The dry residue was dissolved in methanol and injected $(20 \mu \mathrm{L})$ into the HPLC system.

\subsection{HPLC conditions}

HPLC system (Thermo Scientific Spectra SYSTEM) equipped with RP analytical column (ODS2 Hypersil ${ }^{\mathrm{TM}} 250 \mathrm{x}$ 4,6 mm, 5um), UV and FL detectors were used. The mobile phase was composed of 97:3 = methanol:water with flow rate $1.0 \mathrm{~mL} / \mathrm{min}$.

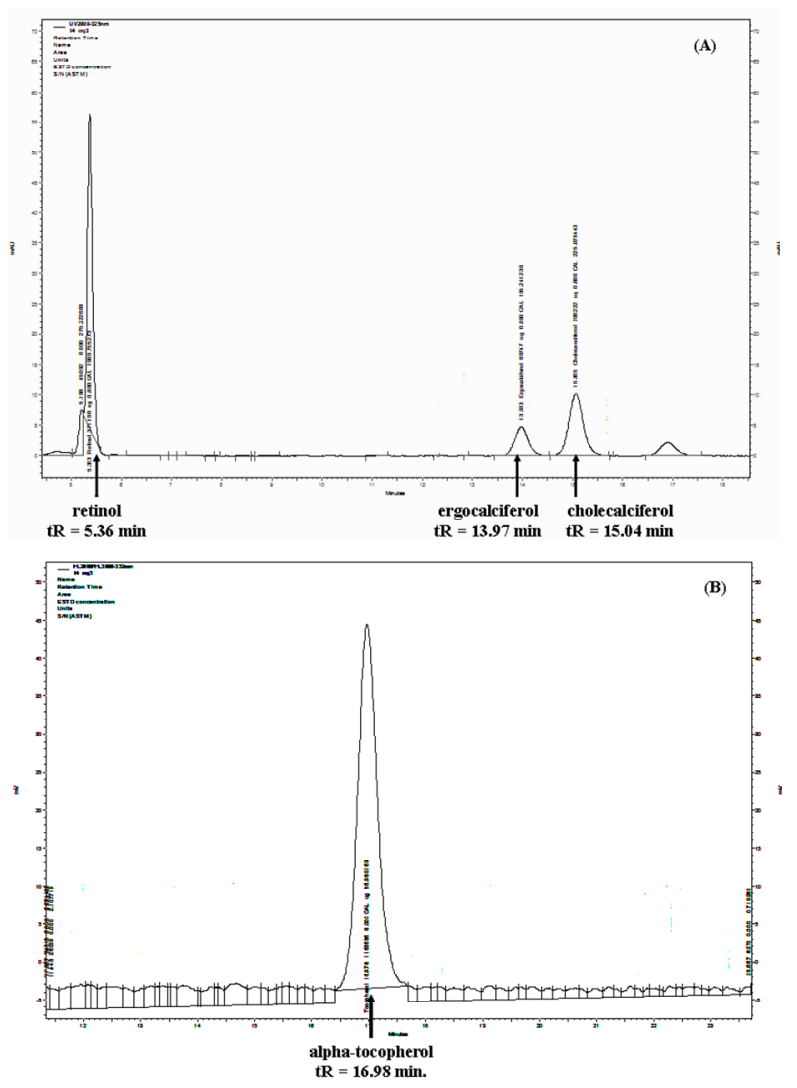

Fig. 1 HPLC chromatograms of fat soluble vitamins' solution (A) Channel 1 - UV detection (B) Channel 2 fluorescence detection 
The qualitative analysis was performed by comparing the retention times of standard solutions of all-trans-retinol, cholecalciferol and alphatocopherol. Retinol and cholecalciferol were monitored by UV detection at $\lambda_{\max }=325 \mathrm{~nm}$ and $\lambda_{\max }=265 \mathrm{~nm}$, respectively (Fig. 1 A). Alphatocopherol was detected by fluorescence at $\lambda_{\text {ex }}=288$ $\mathrm{nm}$ and $\lambda_{\mathrm{em}}=332 \mathrm{~nm}$ (Fig 1. B). The quantitation was done by the method of the external calibration comparing the chromatographic peak areas of the samples with those of the corresponding standards.

\subsection{Statistical analysis}

All samples were analyzed in triplicate. The results were expressed as a mean and standard deviation (mean $\pm \mathrm{SD}$ ), and presented as $\mu \mathrm{g}$ per $100 \mathrm{~g}$ raw tissue $\left(\mu \mathrm{g} \cdot 100 \mathrm{~g}^{-1} \mathrm{rt}\right)$. Statistical analysis was done using GraphPad Prism 5 software. Column statistics was used for calculation of the means, standard deviations, and the coefficients of variation. Student's t-test was used to evaluate the differences between the means. Statistical significance was indicated at $\mathrm{p}<0.05$.

\section{Results and Discussions}

\subsection{Vitamins content}

Both fish species are of commercial importance for many countries. Surprisingly, the data concerning their vitamin content in the scientific literature are very scarce.

In our study a significant differences $(\mathrm{p}<0.05)$ in retinol and alpha-tocopherol contents between fish species were established (Table 2).

Table 2 Fat-soluble vitamins content in edible fish tissue, $\mu \mathrm{g} .100 \mathrm{~g}^{-1}$ (mean $\left.\pm \mathrm{SD}\right)$

\begin{tabular}{|l|c|c|}
\hline Analyte & Turbot & Garfish \\
\hline Retinol & $7.2 \pm 0.6$ & $21.7 \pm 1.4$ \\
\hline Cholecalciferol & $4.6 \pm 0.5$ & $5.8 \pm 0.4$ \\
\hline $\begin{array}{l}\text { alpha- } \\
\text { Tocopherol }\end{array}$ & $2836.8 \pm 96.0$ & $387.5 \pm 32.3$ \\
\hline
\end{tabular}

The content of retinol in garfish was almost three times higher than in turbot.

On the contrary turbot fish reveals seven times higher amounts of alpha-tocopherol than garfish.
Both fishes exhibit very close values for cholecalciferol $\left(5.8 \mu \mathrm{g} \cdot 100 \mathrm{~g}^{-1} \mathrm{rt}\right.$ for garfish and 4.6 $\mu \mathrm{g} \cdot 100 \mathrm{~g}^{-1} \mathrm{rt}$ for turbot). Other authors found out 2.3 $\mu \mathrm{g} \cdot 100 \mathrm{~g}^{-1} \mathrm{rt}$ cholecalciferol in turbot fillets, which is twice as low compared with our data [6].

Our results are in the same order with those presented by the Danish Food Composition Databank, providing data about the vitamins content in raw edible garfish tissue [7]. According to their data the amounts of retinol, cholecalciferol and alpha-tocopherol are $7.0 \mu \mathrm{g} \cdot 100 \mathrm{~g}^{-1} \mathrm{rt}, 5.0 \mu \mathrm{g} \cdot 100 \mathrm{~g}^{-1} \mathrm{rt}$ and $1700.0 \mu \mathrm{g} \cdot 100 \mathrm{~g}^{-1} \mathrm{rt}$, respectively. Retinol and cholecalciferol contents are in the same magnitude with ours, especially those for cholecalciferol [7].

For turbot raw tissue the same databank presents data only for retinol content. The cited amount is $11.7 \mu \mathrm{g} .100 \mathrm{~g}^{-1} \mathrm{rt}$, which is higher than ours (7.2 $\mu \mathrm{g} \cdot 100 \mathrm{~g}^{-1} \mathrm{rt}$ ) [8].

There are dietary standards in Bulgaria for average daily intake of fat soluble vitamins [9]. The quantities of fat soluble vitamins provided by $100 \mathrm{~g}$ raw fish tissue, as a percentage of the average daily allowance, are given in Table 3.

According to that, both analyzed fishes show very low percentages for the daily recomended intake of retinol. For alpha-tocopherol the fillets of raw turbot reveal significantly higher percentagealmost $19 \%$.

Table 3 Percentage of the daily recommended intake of fat soluble vitamins

\begin{tabular}{|l|c|c|}
\hline Analyte & Turbot & Garfish \\
\hline Retinol & $0.96 \%$ & $2.89 \%$ \\
\hline Cholecalciferol & $\mathbf{9 2 . 0 0 \%}$ & $\mathbf{1 1 6 . 0 0 \%}$ \\
\hline alpha-Tocopherol & $18.91 \%$ & $2.58 \%$ \\
\hline
\end{tabular}

In contrast, cholecalciferol content meets the recommended daily needs for both studied fishes$92 \%$ for turbot and $116 \%$ for garfish fillets.

\section{Conclusions}

Two delicious Black sea fishes were analyzed with the aim to evaluate vitamin $A, D_{3}$ and $E$ contents in relation to their nutritional value.

The turbot and the garfish provide considerable amounts of vitamin $\mathrm{D}_{3}$, preserving almost the daily average intake. 


\section{Acknowledgments}

This study was financed by the National Science Fund, Ministry of Education and Science of Bulgaria (Project DVU 440/2008).

\section{References}

* E-mail address: didobreva@gmail.com

[1]. J. Anderson and L. Young, Food and Nutrition series, Colorado State University, Fact Sheet No 9.315 (2008). http://www.ext.colostate. edu/pubs/foodnut/09315.pdf

[2]. *** National Strategic Plan for Fisheries and Aquaculture 2007 - 2013, Ministry of Agriculture and Forestry, Sofia, Bulgaria (2006).

[3]. M. Karapetkova and M. Jivkov, The fishes in Bulgaria, Gea-Libris, Sofia, Bulgaria (2006).

[4]. H. Lago, J. Pena and S.P. Aubourg, Grasas y Aceites, 61 (3), 312-320 (2010).
[5]. D.A. Dobreva, B. Galunska and M. Stancheva, Scripta Scientifica Medica, Varna Medical University, 43 (1) 276-279 (2011).

[6]. U. Ostermeyer and T. Schmidt, European Food Research and Technology, 3-4 (222) 403-413 (2006).

[7]. *** Danish Food Composition Databank, Department of Nutrition, National Food Institute (2009) http://www.foodcomp. $\mathrm{dk} / \mathrm{v} 7 / \mathrm{fcdb}$ _details.asp?FoodId=0082

[8]. ***Danish Food Composition Databank, Department of Nutrition, National Food Institute (2009) http://www.foodcomp. $\mathrm{dk} / \mathrm{v} 7 / \mathrm{fcdb}$ details.asp?FoodId=0211

[9]. ***Ordinance № $23 / 19.07 .2005$ on the physiological feeding of population http://bg.wikipedia.org/wiki/Физиологични_н орми_за_хранене\#сіte_note-echo-9

Submitted: March $4^{\text {th }} 2012$

Accepted in revised form: April $18^{\text {th }} 2012$ 